\title{
Delivering the Responsible Management Agenda - A Framework for Responsible Mindful Management
}

\author{
David Edgar ${ }^{1}$, Estrella Bernal², and García Campayo ${ }^{3}$ \\ ${ }^{1}$ Glasgow School for Business \& Society, Glasgow Caledonian University, Scotland, Tel: +44(0)141 3313180 \\ ${ }^{2}$ Business Management and Organization Department, University of Zaragoza, Spain, Tel: +34(0) 976761000 \\ ${ }^{3}$ Department of Psychiatry, Miguel Servet University Hospital, University of Zaragoza, Spain, Tel: +34(0)976 \\ Email: d.a.edgar@gcu.ac.uk, bercue@unizar.es, jgarcamp@unizar.es
}

\begin{abstract}
The global economic crisis has caused governments and charities to be squeezed in term of resources to meet social and environmental needs. In parallel, social enterprises, volunteering and the "big society" have stepped in to help fill the void. However, this is a smoke screen that covers a bigger problem - the lack of true social responsibility by large corporations. Too often, mention is made of the economic crisis recovery but the crisis is greater than this, it includes social and environmental crisis which quite simply is not recovering nor is it receiving the attention it deserves. This paper explores this contention and through a literature review proposes a holistic approach to better inform business as to its responsibility and how to meet a more responsible management agenda. We propose this through a model based on responsible management and mindful leadership and provide a brief description of a case study as to how mindfulness is starting being used by an Iberian Multi-national to recast the social responsibility agenda and move towards a more responsible management approach to business. Different coaching techniques combined with Nominal Group Technique were used to identify underlying deep values of participants (CEOs). The resultant values can be used by the multinational to construct a theoretical model of responsible management and mindful leadership. One outcome of this model applied to this multinational is the current strategy being developed by the company. This strategy embeds our thinking and considering the high influence of the case multinational in its sector, we believe the use of the Responsible Management and Mindful Leadership Model will be a tool which increases the multinational's capacity to influence crisis recovery in the true sense, considering social and environmental aspects.
\end{abstract}

Key Words: Mindfulness, responsible management, CSR, social crisis

\section{Introduction}

There is little doubt that the global economic crisis impacted hard on many economies and business. While some commentators (Deen 2013) claim the recovery is well under way, there are still economies showing little sign of change (Beams 2013). Clearly, there is still work to be done. When reflecting on the commentaries relating to, and the apparent causes of the crisis, it is clear that greed, personal gain, inward looking business and narrow views of "social" responsibility played a key role. Interestingly, commentary often relates to the financial and economic state of recovery, the need for growth and the degree of debt. However, little if any mention is made of the impacts of the crisis upon society and the degree or state of societal recovery. Instead, we see businesses concern with society to revolve around meeting regulatory requirements, playing at Corporate Social Responsibility and capitalising on unfortunate economies and societies of the developing world. As such, when we reflect on the nature and causes of the crisis and the emphasis on business and business gain, it is no surprise to us as to what the heart of the problem is - a lack of awareness, care or consideration for how to resolve the social crisis. In this respect, business has lost its way; it has lost its true potential to contribute to society as a whole, not only in employment and financial terms but in identifying and solving societal and environmental problem. The prolific growth in Social Enterprises, charity organisations, Social Innovation and volunteering emphasises our point that business as we know it is "passing the buck" or avoiding its wider responsibilities to society. Thus leaving the "social" recovery to others, a gap filled in the past by 
Governments and Charities. Both now squeezed in terms of funding and resources more than ever, and as such unable to deliver.

Visser (2012) captured some of our concerns, and the nature of this shift well when he claimed that "we should judge the success of CSR by whether our communities and eco-systems are getting better or worse", (p7) he then went on to claim "almost every indicator of our social, environmental and ethical health is in decline" (p7). From this stance, Visser stated that the current understanding of "CSR has failed" and that we are in a new "age of responsibility". This forms the basis and main aim of our paper, where we embrace the concept of "Responsible Management" and "Mindful leadership" and through the development of our framework and a mini case of an Iberian multinational organisation, explore how we can use such a concept to encourage more Iberian companies to contribute more fully to crisis recovery, not just financial or economic crisis recovery but true societal recovery.

The paper is structured in three key parts, firstly we explore the literature in the field to highlight the evolution of the core concepts and determine key gaps with regard to the understanding of responsible management and its implementation, we then propose a conceptual framework to fill the gaps and help us better understand how responsible management could be realised and contribute to the crisis recovery, before providing a brief case of an Iberian multinational adopting the principles of mindful leadership and the resulting benefits.

\section{Background}

Responsible Management represents the basis from which we develop our argument but also reflects the evolution and extension of the principles of CSR (Corporate Social Responsibility). As such, to develop the background, we examine what CSR is and where it has evolved to, ending with the concept of Responsible Management and the context of our paper.

\subsection{Corporate Social Responsibility}

The subject of CSR has attracted a lot of attentions with a mass of associated literature. The strategic issues, outputs and reporting of CSR are generally well explored, (Joyner \& Raiborn, 2005, Dashwood 2014) resulting in several initiatives and various calls for 'openness' and 'transparency' (Buelens et al., 2006, Wilburn \& Wilburn, 2014) e.g. Global Reporting Initiative (GRI), a stakeholder perspective to governance (Hillman et al, 2001, Bartkus et al 2002) and Socially Responsible Investment (SRI) index. The GRI framework has become a guideline for most companies in operating their corporate responsibility reporting. Figure 1 highlights the three core elements of the GRI which can be seen to align to the triple bottom line (Elkington, 1994). In effect this represents a focus on the end point, reporting and measuring. It does not reflect an approach which could contribute to crisis recovery, as it is too organisational specific, output driven and static. In the same vein, the UN is attempting to operationalise its approach to CSR through "Responsible Management". This is a UN initiative under UN Global Compact and represented through PRME (Principles for Responsible Management Education) and partners such as Globally Responsible Leadership Initiative (GRLI). This, we believe, is a step in the right direction but an area under-represented.

To fully understand our argument of the obsoleteness of CSR, we need to explore it a little more. 


\section{GLOBAL REPORTING INITIATIVE}

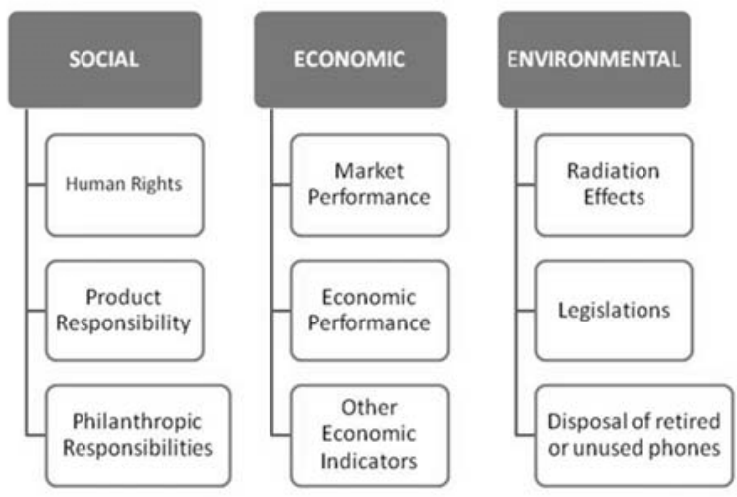

Figure1: GRI reporting (adapted from Rana et al., 2009)

\subsection{Evolution of Corporate Social Responsibility - Time for Change}

With the range of developments and the scope of literature, it is not surprising to find no single definition of CSR. As such, we do not dwell on this. We recognise instead the defining features and the core developments.

The basic definition of the concept of CSR advocated by Bowen in the 1950's viewed the concept as a social responsibility with the obligations of business to pursue policies and decisions or action which was desirable in terms of the objectives and values of society (Bowen cited in Buelens et al., 2006). This was largely based on the premise that the actions of businesses influence the lives of citizens in many respects, an issue not widely recognised in the current crisis recovery. Since the 1950s, the emphasis of CSR has shifted from a focus on shareholders (through to the end of the 1970s), to philanthropy in the 1980s, corporate governance in the early 1990s, stakeholder engagement in the late 1990s, corporate accountability and the triple bottom line in the early 2000s through to sustainable markets and responsible competition now (see Visser 2012). In effect the shift has been from a minimalist effort through to more a stewardship role but its measurement still remains focused on end results and outputs, not the holistic process, indicating a potential lack of process, values, ethos and proactive reflexivity. This is why there is a need to reshape the field and to reflect, refine and reform the understanding of CSR within a context of responsible management, and how such responsible management can help more fully contribute to the crisis recovery.

\subsection{Defining Responsible Management and Its Context with CSR - Moving Forwards}

While CSR itself has become a global concept the implementation of the wider responsible perspective has not kept pace. One key initiative designed to correct this misalignment is the UN PRME initiative, an initiative directed at developing Responsible Leadership through a programme of Management Education with Responsible Management at its heart. However, while CSR has been evolving globally, there is a lack of clarity with regard to definitions and what responsible management actually means or involves within the framework of CSR. Broadly speaking, the concept encompasses an ongoing commitment by an organisation to act ethically and also contribute economically whilst demonstrating respect for people, communities and society at large (Carroll, 1999). Many organisations both profit and non-profit making are now not only viewing responsible management as the right thing to do but also seeking to develop it as a strategic tool that can be employed to gain competitive advantage, increase profitability and also enhance their long term survival. In this regard, Hopkins (2009) cited Toyota's innovative approach of using CSR as a strategic weapon to move ahead of the competition through the pioneering development of hybrid engines that incorporated environmental concerns into its 
manufacturing process thus giving it a competitive advantage over rivals like Ford, General Motors. This, combined with the host of corporate scandals (Enron, WorldCom, Lehman Brothers) has led businesses to consider seriously how to protect their reputation, and resulting wealth creation prospects.

However, what is increasingly prevalent is that CSR is deemed the end point of the process. If the economic crisis is to be recovered then this may work but if the crisis recovery does not embrace the wider recovery of society, environment, and social well-being then it is doomed to failure. In this regard, a more holistic responsible management view of business is required. Therefore, while corporate social responsibility (CSR) has been described as those responsibilities and obligations that compel organisations to pursue or respond to socio-economic and environmental needs in a harmonious manner (Buelens et al., 2006) and measurements have been put in place to control the outputs of the organisation through balanced scorecards and the triple bottom line, little if anything has been done to explore the development of the responsible management mind set (in our terms, mindful leadership) or consolidate the inputs to the responsible management process. We propose that if these can be achieved, business can make a meaningful wider social contribution to resolve the crisis in many economies.

So, what is Responsible Management based on Mindful leadership?

Despite the vast and growing interest in Responsible Management, there is no clarity of definition. Indeed, the UN itself avoids the presentation of a definition in favour of principles and flexibility ${ }^{1}$.

In this regard, before defining Responsible Management based on Mindful leadership, we need to explain a few previous concepts implied in such definition: Mindfulness and Presence.

\subsection{The Concept of Mindfulness}

According to Langer (1989), a western society view of mindfulness, is a state of mind and perception that makes people avoid the old ways of thinking and behaving. It keeps them alert to new possibilities, and requires sharp attention to the present moment. This creates a state of alertness and active awareness that produces and refines categories, opens the perception to new information and existence of multiple perspectives.

On the other hand the Eastern perspective of mindfulness, means a state of mind and perception with receptive attention to and awareness of present events and experience occurring both internally and externally, or moment-to-moment, non-reactive nonjudgmental awareness. (Brown \& Ryan, 2003; Weick \& Putnam, 2006). Mindfulness (in its Eastern perspective), when exercised by any person, produces what we call Presence. In biology of knowledge terms, Presence is a creative element and the source of "love" scientifically defined by Maturana and Varela (1987) in their model as recognizing the "other" as a fellow being with the same essential nature as "I" has as a person - i.e. as a "Thou" in the sense defined by Kofman and Senge (1993). In this context, the attitude on establishing relationships within the organization is that "the other" has an existence and experiential domain that is just as valid as that of the "I" itself. So, the language and consequent description of the world produced by the other's experiential domain will be considered equally legitimate. This is reflected in the approach of Bernal and Edgar (2012) of relational biological ethics, which is relevant in attempting the establishment within the firm of relations based not on power and subordination, but on equality, with full recognition of each other as legitimate beings.

\subsection{Definition of Responsible Management Based on Mindful Leadership}

We define responsible management as "a way of managing that takes actions based on deep values which emerge from the awareness of links with society and environment. It implies total accountability for the full consequences of these actions. Such awareness is a dynamic continuous process vividly linked to present moment and mindfulness, leadership guided by this awareness is a Mindful Leadership".

\subsection{Mindfulness and the Link to Responsible Management}

Applying Mindfulness in its eastern interpretation of "Presence" to business and according to relational biologic ethics, it is a way for the organization to gain socioeconomic and environmental system

\footnotetext{
${ }^{1}$ See http://www.unprme.org/about-prme/the-six-principles.php.
} 
awareness wide enough to consider all the relevant system (social, economic and environmental system) balances when making its decisions to actions, which would lead it to Responsible Management.

According to this approach, such ethical conception within the organization leads to a nurturing that facilitates the emergence of deep values related with authentic individual presence, the experience of our study case supports this hypothesis. Consequently, a Mindful leader is a leader behaving with Presence that structures her/his own values naturally according to the described relational biological ethics. Theoretically, an organization behaving from biological relational ethics, would have a participative leadership within a culture of high commitment, where every member would exercise these values and would be able to lead her/himself and also the job to be accomplished in every moment.

\subsection{Relationship between Responsible Management and Business Performance}

In striving to achieve its goals and objectives an organisation cannot operate in isolation from its environment. The power and influence of businesses should be balanced with its broad values, social responsibility and the contribution (in a wider sense) to society. There is however differing opinions about how a business should act, such as shareholder focussed or stakeholder centred.

The former idea advocated by Friedman and others suggests that businesses have only one social responsibility and that is to maximise profits for its shareholders (Friedman in Buelens, 2006), the pristine capitalist. Critics of this school of thought have argued that businesses serve multiple stakeholder groups whose interests overlap and conflict, Freeman (1984); Friedman and Miles (2002); Henriques and Sadorsky (1999). Understanding such interests and relationships between these stakeholders may compel businesses to act in a more socially responsible way notwithstanding their motivations (Sen, 1993; cited by Buelens et al., 2006). These viewpoints have originated the assumption of the link between investments in social responsibility and improvements in business performance with various attempts being made to either substantiate or disprove the assertion. For example the work of Ullmann (1985) advances the argument that when businesses are seen as economic institutions then a negative relationship could be established between profitability and social responsibility. Others however disagree with this assertion by establishing a causal relationship between socially responsible management and improved financial performance (Alexander \& Bucholz, 1978). However, as Buelens et al (2006) shows, using the supply and demand theory of the firm framework, investment in social responsibility can result in the maximisation of profit while at the same time meeting the needs of stakeholders (employees, customers, community groups etc). In striving to achieve a balance between business goals and responsibility, companies must weigh the costs and benefits of their actions and ensure that they do not become detrimental to their economic and/or competitive performance now and into the future. Those tasked with governance of this process must therefore determine the extent to which the organisation will attempt to meet their social responsibilities and thus implement effective responsible management.

Today's MNCs have become bigger and more powerful than the governments of most countries they trade in and with this shift of resources comes a shift in responsibility to positively and proactively impact the 'world' around them (Gustafson 2006, pp. 302). In addition the turn of the $21^{\text {st }}$ century has seen the growing awareness of the concept in society hence demands for corporate social responsibility and environmental accountability is on the increase (Henriques, 2010). This will ensure that CSR and responsible management will remain high on the agenda of organisations worldwide and not fade. The growing importance of the concept is underscored by the extent of coverage included in the business review of the annual report of most major companies as evidence by the recent KPMG survey on Corporate Responsibility Reporting (KPMG, 2011). Thus, such organisations can provide the solution to the crisis if efforts are reoriented and responsible management implemented and widened in scope. This would require a shift in focus for business practice and thinking away from merely CSR to be more "mindful" about responsible management, adopting co-creation, co-responsibility, stewardship (Hernandez 2008) and mindful leadership, not mindless CSR (Baron, 2013).

Having clarified the nature of the field, the next section will explore the gaps in the literature and set up the various elements of the proposed conceptual framework. 


\section{Research Gaps - The Need for a Conceptual Framework}

Exploring the literature highlights a number of gaps and areas requiring re-orientation. These gaps relate to the emphasis of framework and measurement models and to the potential role of "presence" as a driver of the responsible management process, in effect the role of mindfulness.

\subsection{Reflecting on Our Thinking about Social Responsibility - CSR and Responsible Management}

Given our discussions thus far, it would appear that stakeholders are becoming more and more concerned about the corporate social performance of organisations operations, a claim supported by Epstein-Reeves (2010), and Sommerville (2013). This form of performance leads to our first research gap and the need to reflect on what we measure and why. Performance in this regard can be defined as "a construct that emphasizes a company's responsibilities to multiple stakeholders, such as employees and the community at large, in addition to its traditional responsibilities to economic shareholders" (Turban and Greening 1996, p.658). In line with this, it is becoming increasingly clear that investors are using socially responsible investing (SRI) screens to select or avoid investing in firms according to their environmental and social preferences (Chatterji et al. 2009), and a growing number of consumers purchase eco-labelled products that signal a lower environmental and social impact of corporate operations (Loureiro and Lotade 2005). Some corporations are also developing socially responsible purchasing practices to promote more sustainable supply chains (e.g. Drumwright 1994, Bowen et al. 2001, Srivastava 2007, Carter 2008, Seuring \& Müller 2008). Research in the need for CSR and indeed its measurement are relatively well developed with general agreement that CSR is needed and does add value (economic and social/societal) through various metrics (Gond \& Crane 2009, Rowley \& Berman 2000) and eco-efficiency studies (Dyckhoff \& Allen 2001, Färe et al. 2006, Kuosmanen \& Kortelainen 2007). What is interesting in terms of the studies relating to metrics is the reliance on measuring at an end point, in a linear fashion and around the hard measures of the business e.g. emissions, financial data, customer surveys and the SRI data. However, in reality Responsible Management is highly qualitative in nature and would rely mostly on "soft" measures related to management practices, rather than the "harder" measures mentioned earlier. Several authors have recognised these issues (Carroll 1999, Graves \& Waddock 1994) and the complex and multi-dimensional nature of CSR in terms of the process. As such, we need to reflect on the holistic process of responsible management rather than attempt to measure end points of what is an intertwined process. While our paper makes no attempt to measure the CSR activity we highlight this area as a gap purely in terms of the emphasis placed by studies on the end processes and seek to realign the thinking in the field to be more holistic in nature.

Our next research gap relates to the actors involved in the Responsible Management process and the lack of recognition or understanding of a fundamental element of the process which lies in every person, what we called presence, a result of mindfulness.

From our discussions so far, we believe there is a need to review approaches to considering CSR and Responsible Management, to rebalance around an understanding of the holistic process of being truly "responsible" and to understand the potential and power of "mindfulness". In doing so, we can help organisations navigate the "corporate responsibility" landscape and make a proactive and meaningful contribution to crisis recovery and society as a whole.

\section{A Framework for Responsible Management Mindfulness}

Based on the former discussion and on an extensive literature review, we now present a framework for considering the Responsible Management and Mindful Leadership of organisation built around mindfulness and a holistic view of the "responsible" organisation. Our framework differs from the Freiburg Mindfulness Inventory (Walach et al 2006) in that what we propose is a framework that organisations can use to readdress their position in society and help drive the crisis recovery, rather than the approach to undertaking individual mindfulness itself. 


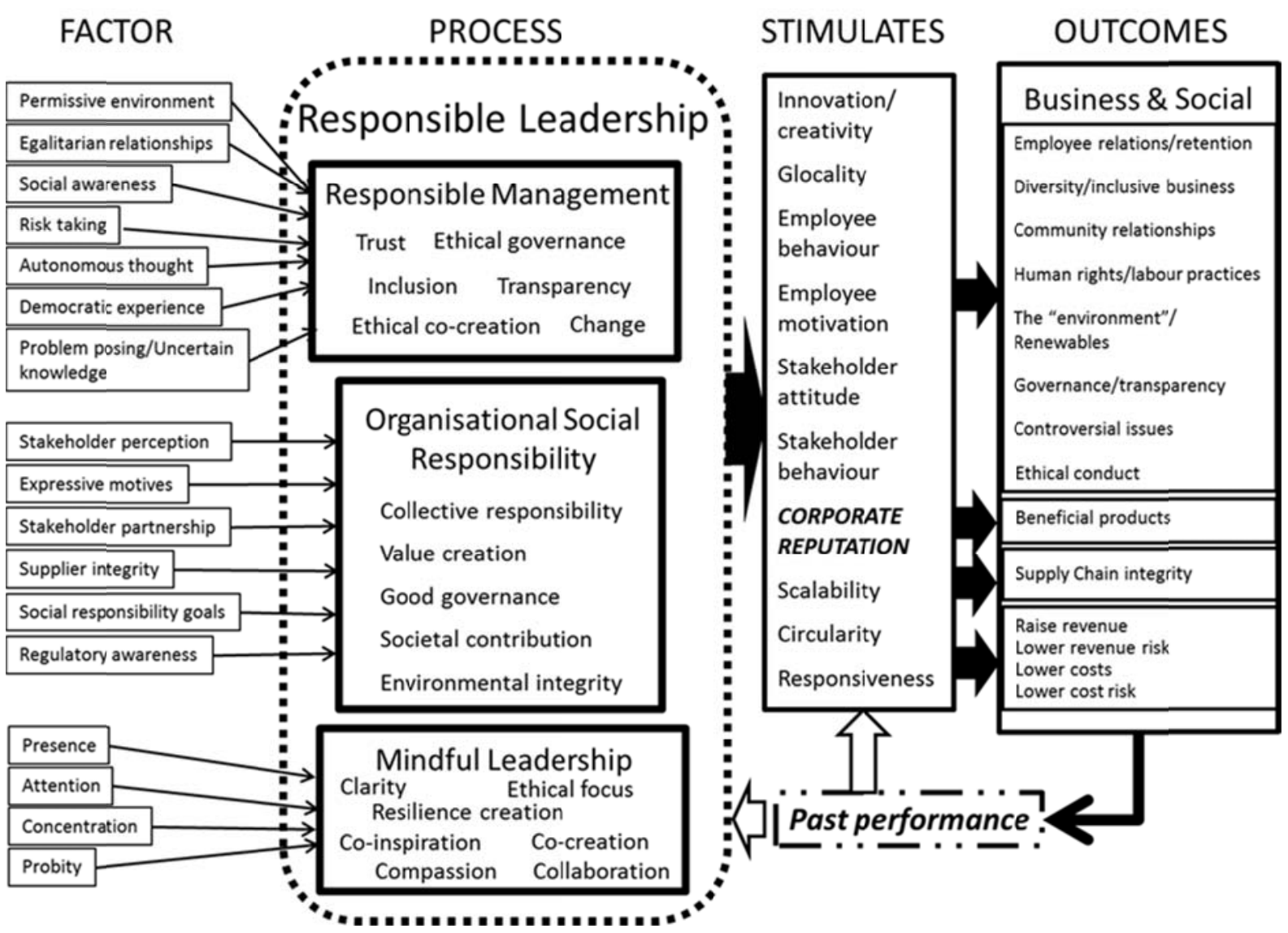

Figure 2: A framework for responsible management and mindful leadership. Source: authors

From figure 2 the framework was developed into distinct phases. The phases reflect the factors or competences to be developed, the processes to be implemented and measured, the resulting stimulus and the end results or outcomes. Take each in turn. At this stage the cause-effect relation is just stated at a theoretical hypothesis level that will be tested in future empirical works.

\subsection{Factors}

The factors identified align to the three core processes involved in Responsible Leadership, namely Responsible Management, Organisational Social Responsibility and Mindful Leadership. The factors represent competences and perspectives that shape and deliver the processes and ultimately reflect the values of the organisation and its ability and willingness to deliver.

Factors linking to Responsible Management have suffered from a degree of acadiemic neglect. Little is written about what components lead to responsible management. Often, the factors are portrayed as a series of principles (UNPRME), generalised behaviours or expected outcomes (Barthel \& Ivanaj 2007), and often focusing on actors or stakeholders (Pedersen 2011, Habisch et al 2011; Christmann, 2004; Eiadat et al 2008, Choi \& Park 2014). While these are helpful to emphasise the importance of responsible management and the potential role it can play in the crisis recovery across the broader domain of society, the existing literature is deeply limiting in terms of guiding how to develop responsible managers or indeed what Responsible Management actually is and can deliver. At the conceptual level, our framework draws upon the work of Hesketh (2006) who proposes a set of components for responsible management education. These components allow for uns to begin to explore the field.

The factors presented are defined in table 1 . 
Table 1: Factors influencing responsible management. Source: authors, adapted from hesketh 2006.

\begin{tabular}{|c|c|c|}
\hline Factor & Description & Link to Responsible Mngt \\
\hline $\begin{array}{l}\text { Permissive } \\
\text { environment }\end{array}$ & $\begin{array}{l}\text { Staffs have control, intent and capability to } \\
\text { deliver the objectives. }\end{array}$ & $\begin{array}{l}\text { To allow the proactiveness, reflexivity and } \\
\text { responsiveness to identify and meet social, } \\
\text { business and ecological challenges }\end{array}$ \\
\hline $\begin{array}{l}\text { Egalitarian } \\
\text { relationships }\end{array}$ & People are equal in relationships & $\begin{array}{l}\text { This helps deliver the trust, inclusiveness and } \\
\text { transparency needed to make responsible } \\
\text { management work }\end{array}$ \\
\hline Social awareness & $\begin{array}{l}\text { actively seeking out information about what is } \\
\text { happening in the communities around in and } \\
\text { around the organisation e.g. social norms }\end{array}$ & $\begin{array}{l}\text { Decision-makers need to understand and } \\
\text { make sense of what is happening around } \\
\text { about them in terms of the social setting and } \\
\text { potential actions and reactions. }\end{array}$ \\
\hline Risk taking & $\begin{array}{l}\text { Activity that could cause damage or harm but } \\
\text { allows for potential rewards }\end{array}$ & $\begin{array}{l}\text { For real change to occur, risk taking is } \\
\text { needed. This helps break the conventional } \\
\text { norms and provides for novel and alternative } \\
\text { solutions }\end{array}$ \\
\hline $\begin{array}{l}\text { Autonomous } \\
\text { thought }\end{array}$ & $\begin{array}{l}\text { The ability of decision-makers to think } \\
\text { independently }\end{array}$ & $\begin{array}{l}\text { Thinking independently helps facilitate } \\
\text { ethical governance by freeing the mind from } \\
\text { "mental slavery" and group think. }\end{array}$ \\
\hline $\begin{array}{l}\text { Democratic } \\
\text { experience }\end{array}$ & $\begin{array}{l}\text { Collaboration is encouraged and collaborative } \\
\text { decision-making welcomed }\end{array}$ & $\begin{array}{l}\text { Responsible management is enhanced by } \\
\text { multiple views, sharing of knowledge and } \\
\text { learning. These occur through collaborative } \\
\text { practices and provide for "buy-in" }\end{array}$ \\
\hline $\begin{array}{l}\text { Problem } \\
\text { posing/Uncertain } \\
\text { knowledge }\end{array}$ & $\begin{array}{l}\text { Gathering dynamic information from a variety } \\
\text { of changing sources. Acknowledgement of the } \\
\text { different sources and kinds of uncertainty, } \\
\text { many of which are not reducible. }\end{array}$ & $\begin{array}{l}\text { The questioning and continual learning } \\
\text { required with uncertain knowledge facilitates } \\
\text { a continual process of refreshment in } \\
\text { thinking and practice }\end{array}$ \\
\hline
\end{tabular}

In our model the factors represent the foundation of the competences of responsible management.

The factors influencing the Organisational Social Responsibility are widely researched but not often empirically defended. Inoune and Lee (2010) claimed that the multidimensional nature of Social Responsibility makes this a very tricky task. This was supported by Sheldon and Park (2010), WBCSD (2011) and El Dief and Font (2010). The factors we proposed are derived from the work of Durden (2007), Broomhill (2007), and Maklan and Knox (2003), and are grouped around stakeholder influences (Hart 1995, Russo \& Fonts 1997, Berman et al 1999), expressive motives (Williams 2007), suppliers and supply chain (Seuring \& Muller 2008, Salam 2009, Carter 2008, Srivastava 2007, Bowen et al 2001, and Drumwright 1994), social responsibility goals (Maklan and Knox 2003), and regulatory awareness (Eiadat et al 2008).

The factors influencing Organisational Social Responsibility are presented in table 2.

The final group of factors relate to the core of mindful leadership. As we explained when defining Responsible Management, Mindful leadership is based on the Presence. Recent literature on psychology and behavioural sciences (i.e. Chiesa et al. (2013); Berkovich-Ohana et al. (2012); Ravnik-Glavač et al. (2012)) applied to Mindfulness, supports the idea that applying Mindfulness produces total attention to the present moment, as well as concentration to apply the best needed knowledge in every circumstance. Consequently these factors imply probity in every action which allows for right accountability. In figure 3 , we just show that the concentration and attention training are also necessary conditions to develop presence, so there is a bidirectional relation among them and Presence (Kabat-Zinn 2003a, 2003b; Ludwig \& Kabat-Zinn 2008). 
Table 2: Factors influencing organisational social responsibility.

\begin{tabular}{|c|c|c|c|}
\hline Factor & Description & Link to Org Social Resp & Source \\
\hline $\begin{array}{l}\text { Stakeholder } \\
\text { perception }\end{array}$ & $\begin{array}{l}\text { There is a vast array of } \\
\text { potential stakeholders. This } \\
\text { factor involves understanding } \\
\text { their values, needs, wants and } \\
\text { frames of reference. }\end{array}$ & $\begin{array}{l}\text { Understanding the stakeholders allows the } \\
\text { firm to be responsive but also predictive of } \\
\text { potential stakeholder reactions }\end{array}$ & $\begin{array}{l}\text { Hart } 1995, \text { Russo } \\
\text { and Fonts } 1997, \\
\text { Berman et al } 1999\end{array}$ \\
\hline $\begin{array}{l}\text { Expressive } \\
\text { motives }\end{array}$ & $\begin{array}{l}\text { Acts that reveal or emphasise } \\
\text { the identity of the person e.g. } \\
\text { a consumer buys ecological } \\
\text { goods to appear "green" and } \\
\text { express their identity in this } \\
\text { way. }\end{array}$ & $\begin{array}{l}\text { The expressive motives link to value } \\
\text { creation in that they can be managed but } \\
\text { also the communities can be connected and } \\
\text { informed via tools such as social media }\end{array}$ & Williams 2007 \\
\hline $\begin{array}{l}\text { Stakeholder } \\
\text { partnership }\end{array}$ & $\begin{array}{l}\text { Involving and engaging with } \\
\text { the various stakeholders and } \\
\text { communities }\end{array}$ & $\begin{array}{l}\text { Working with stakeholders through a } \\
\text { partnership perspective allows for collective } \\
\text { responsibility and raises the changes of } \\
\text { potential change and impact }\end{array}$ & $\begin{array}{l}\text { Hart } 1995, \text { Russo } \\
\text { and Fonts } 1997, \\
\text { Berman et al } 1999\end{array}$ \\
\hline $\begin{array}{l}\text { Supplier } \\
\text { integrity }\end{array}$ & $\begin{array}{l}\text { The degree to which suppliers } \\
\text { maintain values, standards } \\
\text { and ethics in line with the } \\
\text { responsible stance of the host } \\
\text { organisation }\end{array}$ & $\begin{array}{l}\text { The organisation is only as good as its } \\
\text { weakest link. In this regard, suppliers and } \\
\text { distribution channels need to maintain the } \\
\text { same or higher degrees of responsible } \\
\text { integrity thus strengthening the chain and } \\
\text { improving the overall impact of the firm }\end{array}$ & $\begin{array}{l}\text { Seuring and Muller } \\
2008, \text { Salam } 2009, \\
\text { Carter 2008, } \\
\text { Srivastava 2007, } \\
\text { Bowen et al 2001, } \\
\text { Drumwright } 1994 \\
\end{array}$ \\
\hline $\begin{array}{l}\text { Social } \\
\text { responsibility } \\
\text { goals }\end{array}$ & $\begin{array}{l}\text { The desired targets which the } \\
\text { organisations commits to } \\
\text { achieve regarding its social } \\
\text { responsibility }\end{array}$ & $\begin{array}{l}\text { With flexibility and responsibility comes a } \\
\text { need for clarity of purpose and intent. To } \\
\text { allow staff and stakeholders this freedom } \\
\text { means a need for clear goals relating to } \\
\text { plans, processes and actions linked to } \\
\text { society and business influences }\end{array}$ & $\begin{array}{l}\text { Maklan and Knox } \\
2003\end{array}$ \\
\hline $\begin{array}{l}\text { Regulatory } \\
\text { awareness }\end{array}$ & $\begin{array}{l}\text { Awareness, understanding } \\
\text { and awareness of implications } \\
\text { of local, national and } \\
\text { international regulations. }\end{array}$ & $\begin{array}{l}\text { While organisations can exceed the law } \\
\text { when acting in the way most responsible, } \\
\text { they also need to understand the existing } \\
\text { rules, laws and regulations to ensure } \\
\text { compliance or make a case for alternative } \\
\text { compliance }\end{array}$ & Eiadat et al 2008 \\
\hline
\end{tabular}

Figure 3: Presence-attention/concentration-probity relations. Source: authors

The factors influencing Mindful Leadership are presented in table 3.

Having explored the factors influencing the processes, we now turn our attention to the three core processes in Responsible Leadership, namely Responsible Management, Organisational Social Responsibility and Mindful Leadership. 
Table 3: Factors influencing mindful leadership.

\begin{tabular}{|c|c|c|c|}
\hline Factor & Description & Link to Mindful Leadership & Source \\
\hline Presence & $\begin{array}{l}\text { A state of mind and perception with } \\
\text { receptive attention to and awareness of } \\
\text { present events and experience occurring } \\
\text { both internally and externally, or } \\
\text { moment-to-moment, non-reactive } \\
\text { nonjudgmental awareness }\end{array}$ & $\begin{array}{l}\text { It allows for coherence between } \\
\text { deep values and acting, which is a } \\
\text { source of commitment and energy } \\
\text { for organisational members }\end{array}$ & $\begin{array}{l}\text { Kabat-Zinn } \\
\text { 2003a, 2003b; } \\
\text { Ludwig and } \\
\text { Kabat-Zinn } 2008\end{array}$ \\
\hline Attention & $\begin{array}{l}\text { The focusing of a person's consciousness } \\
\text { in a particular element at a particular } \\
\text { present moment }\end{array}$ & $\begin{array}{l}\text { It sharpens the collection of } \\
\text { relevant information when } \\
\text { making decisions }\end{array}$ & $\begin{array}{l}\text { Chiesa et al.2013, } \\
\text { Berkovich-Ohana } \\
\text { et al } 2012 \text {, }\end{array}$ \\
\hline Concentration & The will of paying attention & $\begin{array}{l}\text { It builds character and habit of } \\
\text { paying attention }\end{array}$ & $\begin{array}{l}\text { Ravnik-Glavač et } \\
\text { al.2012 }\end{array}$ \\
\hline Probity & $\begin{array}{l}\text { The harmonising quality of acting with } \\
\text { Presence in total attention to present } \\
\text { moment, which allows for honest } \\
\text { accountability of any action }\end{array}$ & $\begin{array}{l}\text { Probity contributes to generate } \\
\text { commitment of collaborators } \\
\text { inviting them to also participate } \\
\text { in leadership }\end{array}$ & $\begin{array}{l}\text { Ludwig and } \\
\text { Kabat-Zinn } 2008\end{array}$ \\
\hline
\end{tabular}

\subsection{Processes}

In making sense of the disparate and limited field surrounding responsible management, we explored a range of literature borrowed from domains of psychology, sociology, health and eco-sciences. The review highlighted six core elements to the understanding and operationalising of Responsible Management. The elements which emerged were trust (Caldwell et al 2010), ethical governance (Manz et al 2008, Guay et al 2004), inclusion (Maak \& Pless 2006), transparency (Gardner et al 2011), Ethical cocreation/objectivity (Kempster et al 2011, Worden 2003) and willingness to embrace change (Nijhof et al 2000).

Table 4 provides an explanation of each element.

Table 4: Elements of responsible management.

\begin{tabular}{l|l|l}
\hline \multicolumn{1}{c|}{ Element } & \multicolumn{1}{c}{ Description } & \multicolumn{1}{c}{ Source } \\
\hline Trust & $\begin{array}{l}\text { To rely on the integrity, strength, truth, professionalism of a person or } \\
\text { organisation }\end{array}$ & Caldwell et al 2010 \\
\hline $\begin{array}{l}\text { Ethical } \\
\text { governance }\end{array}$ & Transparency and openness, run on good ethical principles & $\begin{array}{l}\text { Manz et al 2008, Guay } \\
\text { et al 2004 }\end{array}$ \\
\hline Inclusion & Involving others directly or indirectly & Maak and Pless 2006 \\
\hline Transparency & Easy for stakeholders to see what action are performed & Gardner et al 2011 \\
\hline $\begin{array}{l}\text { Ethical co- } \\
\text { creation }\end{array}$ & $\begin{array}{l}\text { Ethical behaviour starts at the moment we listen to everybody's views } \\
\text { and generate a respectful flow of information in which we co-create } \\
\text { ethical decisions and behaviours }\end{array}$ & $\begin{array}{l}\text { Kempster et al 2011, } \\
\text { Worden 2003 }\end{array}$ \\
\hline Change & The ability and willingness to move from the current form & Nijhof et al 2000 \\
\hline
\end{tabular}

The second process within our framework is that of Organisational Social Responsibility.

As we highlighted in the background section, a considerable degree of work has been undertaken into exploring CSR but that this has in effect detracted from the wider picture of organisational responsibility per se (Houdre 2008, and Sheldon \& Park 2010). As such, in this section of the framework we consolidate the core elements of Organisational Social Responsibility as a broader concept and one which we hope will encourage organisations to embrace a wider remit of "social responsibility" that reflects what Visser (2012) would recognise as Stakeholder stewardship.

Table 5 provides an explanation of each element. Much of this is developed from Visser's (2012) work. 
Table 5: Elements of organisational social responsibility. Source: authors, adapted from Visser 2012

\begin{tabular}{l|l}
\hline \multicolumn{1}{c|}{ Element } & \multicolumn{1}{c}{ Description } \\
\hline $\begin{array}{l}\text { Collective } \\
\text { responsibility }\end{array}$ & Responsibility shared across different value sets and context \\
\hline Value creation & $\begin{array}{l}\text { Economic development creating social and economic value through inclusive business and } \\
\text { beneficial products. Can include economic, political, social, emotional, or cognitive value }\end{array}$ \\
\hline Good governance & Leadership, transparency and ethical practices. \\
\hline Societal Contribution & A stakeholder orientation that fulfils more than just a narrow contribution \\
\hline $\begin{array}{l}\text { Environmental } \\
\text { integrity }\end{array}$ & Sustaining and protecting the eco-system. \\
\hline
\end{tabular}

Table 6: Elements of mindful leadership. Source: authors

\begin{tabular}{|c|c|c|}
\hline Element & Description & Source \\
\hline Clarity & $\begin{array}{l}\text { A state of quiet mind produced by using it just when necessary, } \\
\text { getting rid of useless elements within mental activity and naturally } \\
\text { focusing on what is related to the vital process to be managed at } \\
\text { that very present moment }\end{array}$ & $\begin{array}{l}\text { Hollis-Walker and Colosimo } \\
\text { 2011, Stanley 2012, Keng et } \\
\text { al 2011, }\end{array}$ \\
\hline $\begin{array}{l}\text { Resilience } \\
\text { creation }\end{array}$ & $\begin{array}{l}\text { The ability of creating capability in the system to be managed to } \\
\text { react and come back to balance after a shock that takes it out of } \\
\text { its usual path. This creation happens by having a systemic } \\
\text { approach that allows to manage beyond efficiency and efficacy to } \\
\text { take into account all the relevant relations within the system that } \\
\text { have to be respected and looked after in order to keep them in } \\
\text { good state enabling them to react when necessary }\end{array}$ & $\begin{array}{l}\text { Keng et al 2011, Garland et } \\
\text { al. 2009, Ly and Spezio } \\
\text { 2009, Carson et al. } 2004\end{array}$ \\
\hline Ethical focus & $\begin{array}{l}\text { The natural result from probity coming from total attention to } \\
\text { what is in the first place fundamental, related to essence of human } \\
\text { beings and respect to life in all its different manifestations, a } \\
\text { respect that generates human relations of equality and generates } \\
\text { real dialogue with active listening and genuine expression of } \\
\text { feelings and thoughts }\end{array}$ & $\begin{array}{l}\text { Hollis-Walker and Colosimo } \\
\text { 2011, Stanley 2012, Keng et } \\
\text { al 2011, Garland et al. 2009, } \\
\text { Ly and Spezio 2009, Carson } \\
\text { et al. 2004, Maturana and } \\
\text { Varela } 1987\end{array}$ \\
\hline Compassion & $\begin{array}{l}\text { The capability of feeling unity with the rest of human beings and } \\
\text { therefore feeling their feelings as if they were own feelings }\end{array}$ & $\begin{array}{l}\text { Stanley 2012, Carson et al. } \\
2004\end{array}$ \\
\hline Co-inspiration & $\begin{array}{l}\text { The result of real dialogue in which each different part of a human } \\
\text { group express their view of the situation while being considered as } \\
\text { legitimate by the others. In the real listening during Co-inspiration, } \\
\text { each member of a group provides part of the inspiration to } \\
\text { generate wider domains of meanings from reality producing richer } \\
\text { and different options to make decisions }\end{array}$ & $\begin{array}{l}\text { Hollis-Walker and Colosimo } \\
\text { 2011, Stanley 2012, Keng et } \\
\text { al 2011, Carson et al. 2004, } \\
\text { Maturana and Varela } 1987\end{array}$ \\
\hline Co-Creation & $\begin{array}{l}\text { The acceptance of the view of the reality the group creates based } \\
\text { on their co-inspiration, and the commitment to work for it. }\end{array}$ & $\begin{array}{l}\text { Hollis-Walker and Colosimo } \\
2011 \text {, Stanley 2012, Keng et } \\
\text { al } 2011\end{array}$ \\
\hline Collaboration & $\begin{array}{l}\text { The genuine energy of every individual working committed to the } \\
\text { view generated by the group, in the awareness that it is being built } \\
\text { based on the respect to each individual vision. }\end{array}$ & $\begin{array}{l}\text { Hollis-Walker and Colosimo } \\
\text { 2011, Stanley 2012, Keng et } \\
\text { al 2011, Garland et al. 2009, } \\
\text { Ly and Spezio 2009, Carson } \\
\text { et al. } 2004\end{array}$ \\
\hline
\end{tabular}

As a consequence of Mindfulness, Mindful leadership process generates several elements as Compassion, Clarity, Creativity, Resilience and Ethical focus (Hollis-Walker \& Colosimo (2011); Stanley (2012); Keng et al (2011); Garland et al. (2009); Ly \& Spezio (2009); Carson et al. (2004)). Such ethical focus that we proposed related to biology of knowledge models (relational biologic ethics), involves also co-inspiration, co-creation and compassion. 
Table 6 provides an explanation of each element.

\subsection{Stimulates}

In this section, we make no claims of cause and effect. We simply seek to highlight what common actions appear to occur from the factors and processes as identified by previous studies. In table 7 we propose that there are a range of "soft" skills, processes and elements that can stimulate a positive responsible outcome. The most prominent item is that of corporate reputation (Maklan \& Knox 2003). There are many studies exploring the impacts of ethical mishaps on the reputation of the organisation and the resulting actions required to "Clean up the mess". Of the same accord a positive responsible experience enhancing the reputation of the organisation and can result in customer trust, loyalty and retention (Fassin \& Gosselin 2011, Freeman \& Auster 2011, Spiller 2000, Hansen 2009). The other elements of the framework emerge from a range of studies. One most prominent is the work by Visser (2012) identifying creativity, Glocality, Scalability, Circularity and Responsiveness as key item. These items are also supported by the other authors including those exploring innovation, Employee behaviour (Tams \& Marshall 2011, O’Higgins \& Kelleher 2005), Employee motivation (Harshman \& Harshman 1999, Doh et al 2011), Stakeholders (Durden 2007, van Marrewijk 2004, Maak \& Pless 2006) and responsiveness.

Table 7: Items occurring from the factors and processes.

\begin{tabular}{|c|c|c|}
\hline Item & Description & Source \\
\hline $\begin{array}{l}\text { Innovation/ } \\
\text { creativity }\end{array}$ & $\begin{array}{l}\text { New ideas and adaption or adoption of existing ideas } \\
\text { directed to solving the world's social and } \\
\text { environmental problems }\end{array}$ & Visser 2012 \\
\hline Glocality & $\begin{array}{l}\text { 'glocalization' comes from the Japanese dochakuka, } \\
\text { meaning global localization. (Visser 2012) }\end{array}$ & Visser 2012 \\
\hline $\begin{array}{l}\text { Employee } \\
\text { behaviour }\end{array}$ & $\begin{array}{l}\text { How employees act within and outwith the } \\
\text { organisation }\end{array}$ & $\begin{array}{l}\text { Tams and Marshall 2011, O'Higgins and } \\
\text { Kelleher 2005, Fassin and Gosselin 2011, } \\
\text { Freeman and Auster 2011, Spiller 2000, } \\
\text { Hansen } 2009\end{array}$ \\
\hline $\begin{array}{l}\text { Employee } \\
\text { motivation }\end{array}$ & Influences on a person behaviour in an organisation & $\begin{array}{l}\text { Harshman and Harshman 1999, Doh et al } \\
\text { 2011, Fassin and Gosselin 2011, Freeman } \\
\text { and Auster } 2011\end{array}$ \\
\hline $\begin{array}{l}\text { Stakeholder } \\
\text { attitude }\end{array}$ & The view the stakeholders hold of the organisation & $\begin{array}{l}\text { Durden 2007, van Marrewijk 2004, Maak } \\
\text { and Pless } 2006\end{array}$ \\
\hline $\begin{array}{l}\text { Stakeholder } \\
\text { behaviour }\end{array}$ & The action the stakeholder takes & \\
\hline $\begin{array}{l}\text { Corporate } \\
\text { reputation }\end{array}$ & $\begin{array}{l}\text { The collective assessments of an organisation's past } \\
\text { actions and ability to deliver improvements for } \\
\text { stakeholders into the future. }\end{array}$ & Maklan and Knox 2003 \\
\hline Scalability & $\begin{array}{l}\text { The ability to handle a growth in the scale of the } \\
\text { work capably }\end{array}$ & Visser 2012 \\
\hline Circularity & $\begin{array}{l}\text { The cradle-to-cradle nature of the resources used and } \\
\text { products sold by an organisation }\end{array}$ & Visser 2012 \\
\hline Responsiveness & Agility, flexibility and willingness to meet a need & Maak and Pless 2006 \\
\hline
\end{tabular}

\subsection{Outcomes}

The outcomes represent common measures, outcomes, and benefits attributed to Responsible Management, leadership and CSR.

It was around the 1970's that definitions of CSR became more specific and resulted in a shift in paradigm towards Corporate Social Responsiveness. At this point Corporate Social Performance found its way into literature (Buelens et al., 2006) and measures of "social responsiveness" became more 
prominent (Caroll 1999). The era of the 1980's and 1990's saw the emergence of new alternatives for CSR like Business Ethics Theory, Corporate Citizenship and Stakeholder Theory with measures of outcomes broadening but still remaining around the "what could be measured" domain e.g. emission, retention, charitable giving. In the new millennium investors and consumers began to take more interest in the responsibility and ethical stance of companies and as such, investment houses in particular, began to attempt to quantify how responsible companies were (using index like SRI). The complexity of this task was soon evident (Gond \& Crane 2009, Rowley \& Berman 2000) and most measures remained around traditional CSR perspectives. However a clear distinction had now been made between CSR and what Dawkins (2002) termed Corporate Citizenship, giving emphasis to the fact that organisations are members of society. Extending the measures of output along this domain and in the spirit of responsible management leads to quantifiable business measures (Margolis \& Walsh 2003, Margolis et al 2007) of revenue, cost, employee retention, gender balance, governance reporting, emissions, recycling, and responsibility reporting, as well as more societal outputs and measures around community engagement, human rights, beneficial products (Visser 2012) and supply chain integrity. Thus a range of outcomes have been included in the framework. These outcomes also align to ISO26000 on Social responsibility in recognition that many developing economies are taking up such standards in their pursuit of what we hope will be responsible management.

Table 8 summarises these outcomes divided into general categories of traditional business and more intangible, qualitative social oriented measures.

Table 8: Items occurring from the factors and processes.

\begin{tabular}{|c|c|c|}
\hline Outcome & Description & Source \\
\hline $\begin{array}{l}\text { Employee } \\
\text { relations/retention }\end{array}$ & $\begin{array}{l}\text { The degree to which the organisation becomes an employer of } \\
\text { choice, holds onto talent and continues to attract the best talent }\end{array}$ & Buelens et al., 2006 \\
\hline $\begin{array}{l}\text { Diversity/ } \\
\text { inclusive business }\end{array}$ & $\begin{array}{l}\text { The extent to which individuals outside of the dominant } \\
\text { employment group are given opportunities within the workplace }\end{array}$ & Buelens et al., 2006 \\
\hline $\begin{array}{l}\text { Community } \\
\text { relationships }\end{array}$ & $\begin{array}{l}\text { The degree to which the organisation establishes and maintains } \\
\text { mutually beneficial engagements with a variety of stakeholder } \\
\text { groups }\end{array}$ & Dawkins 2002 \\
\hline $\begin{array}{l}\text { Human rights/ } \\
\text { labour practices }\end{array}$ & $\begin{array}{l}\text { Meeting and exceed regulatory and advisory HR practices and } \\
\text { actions related to Human well-being }\end{array}$ & Caroll 1999, \\
\hline $\begin{array}{l}\text { The environment/ } \\
\text { renewables }\end{array}$ & $\begin{array}{l}\text { The measure of waste, recycling, eco-efficiency of the } \\
\text { organisation }\end{array}$ & Caroll 1999, \\
\hline $\begin{array}{l}\text { Governance/ } \\
\text { transparency }\end{array}$ & $\begin{array}{l}\text { How the organisation is operated and openness of reporting and } \\
\text { decision-making }\end{array}$ & Buelens et al., 2006 \\
\hline $\begin{array}{l}\text { Controversial } \\
\text { issues }\end{array}$ & $\begin{array}{l}\text { The number of controversial issues that arise associated with the } \\
\text { operations of the organisation }\end{array}$ & $\begin{array}{l}\text { Gond and Crane 2009, } \\
\text { Buelens et al., 2006, } \\
\text { Rowley and Berman } 2000 \\
\end{array}$ \\
\hline Ethical conduct & How the organisation responds to ethical issues & $\begin{array}{l}\text { Gond and Crane 2009, } \\
\text { Rowley and Berman } 2000\end{array}$ \\
\hline $\begin{array}{l}\text { Beneficial } \\
\text { products }\end{array}$ & $\begin{array}{l}\text { The development of products with benefits to society in their } \\
\text { production, use or re-use. }\end{array}$ & Visser 2012 \\
\hline $\begin{array}{l}\text { Supply Chain } \\
\text { integrity }\end{array}$ & $\begin{array}{l}\text { The degree to which the organisations suppliers align to meet } \\
\text { the values and "responsible" standard of the organisation }\end{array}$ & Visser 2012 \\
\hline Raise revenue & $\begin{array}{l}\text { Increase in revenue, customer retention, customer affinity and } \\
\text { customer loyalty }\end{array}$ & $\begin{array}{l}\text { Margolis and Walsh 2003, } \\
\text { Margolis et al } 2007\end{array}$ \\
\hline $\begin{array}{l}\text { Lower revenue } \\
\text { risk }\end{array}$ & $\begin{array}{l}\text { Reduced revenue volatility, permission to operate (Govt) and } \\
\text { grow. }\end{array}$ & $\begin{array}{l}\text { Margolis and Walsh 2003, } \\
\text { Margolis et al } 2007\end{array}$ \\
\hline Lowers costs & $\begin{array}{l}\text { Lower outgoings due to staff retention and better commitment, } \\
\text { reduced waste and energy costs and increased productivity }\end{array}$ & $\begin{array}{l}\text { Margolis and Walsh 2003, } \\
\text { Margolis et al } 2007\end{array}$ \\
\hline Lower cost risk & $\begin{array}{l}\text { Less ecological impact, employee and society impacts and } \\
\text { intervention from regulators or Government }\end{array}$ & $\begin{array}{l}\text { Margolis and Walsh 2003, } \\
\text { Margolis et al } 2007\end{array}$ \\
\hline
\end{tabular}


The model is closed by a learning feedback loop that allows the consideration of "past performance" and a reflective and reflexive approach to resolve or capitalise on the outcomes of the system. Understanding such a system allows organisations to reflect and find their way again. Adjusting their ethical and social compass enhances the wider contribution to recovery from the crisis for Iberian multinationals and acts as a catalyst for others to follow.

\section{$5 \quad$ Mindfulness in Action - A Brief Case but a Big Change}

With the sole purpose of exploring the potential of mindfulness, we used as a starting point, an experience with the implementation of mindfulness in leadership and management of a big multinational. We chose an industrial Iberian multinational employing 10000 workers and carried out the experience of starting to introduce middle managers and CEOs into the experience Mindfulness. The context we used was relating to deciding on the values that would constitute the company's next long term strategy and embedding Responsible Management, Responsible Leadership as well as Organisational Social Responsibility.

We first developed a pilot project in one of its business areas. The objectives were to diagnose what its current culture and values (inertial and emergent) are in relation with sustainability concept and to catch economic, environmental and social criteria that participants find relevant to asses if a particular set of values will facilitate more or less than other the company performance for global sustainability.

The pilot project proved to be effective and coherent with the aim to make the organizational values of sustainability emerge; we included every manager (of any level) of the company within a wider participative process with six different Focus Groups. We had 53 managers belonging to every business areas and countries of the company and including the corporative management team as well as the Human Resources management team, organized in 6 focus groups. The results were validated by the trade union leaders in their international committee.

In introducing the Mindfulness experience, we used Nominal Group Technique combined with different coaching tools. Ontological coaching and constructivist coaching exercises of sophrology, in order to establish connection between the right and left part of the brain and the whole body, giving the participants access to their deep creative level in total attention to present moment to facilitate the conscious emergence of their deep values. One of the evidences we had and many participants manifested was the experience of total attention to present moment, and the chance it gives to have access to the deep genuine creative part of their beings where authentic personal values rest, their inner self (Choi \& Gray, 2008), a part that cannot be accessed easily in everyday inertia, since external dominant values overlap guiding behavior. The chance to share deep values and create a shared vision builds the base for the future strategy of the company (much in-line with Hess \& Broughton, 2014) in which the outcomes of our proposed model are seen as part of the possible future scenarios to which the company wants to lead the strategy.

In this way, we started the process of Mindful leadership which has leaded the company to the starting of the processes of Organizational Social Responsibility and Responsible Management. This has been applied through the implementation in the coming strategy of the company of the values that emerged within the Mindfulness process implemented to create the future vision of the company, such values have a high degree of coincidence with the defined elements of the three process of our model (Responsible Management, Mindful Leadership and Organizational Social Responsibility).

This multinational is leader in its sector, in the last two decades it has not stopped innovating in technology (having the most advanced processes in its sector) and growing by investing in different countries with acquisitions of other companies with productive plants to add to its vertical integrated global productive system, moreover, this company has negotiating power enough with its suppliers and clients to establish an objective of demanding them a certain degree of social and environmental performance. The Mindfulness process and Mindful Leadership that supports Responsible Management, has given strength in this company to the vision of keeping a leader position of the company while getting the outcomes (economic, social and environmental) that we propose in our model, being the responsible relations with suppliers and clients they want to reassert a sample of it. 


\section{Conclusions, Limitations and Further Research}

Our paper has explored the development of CSR and concept of Responsible Management. During this journey we have highlighted and examined how the current thinking in the field of "corporate responsibility" does not allow for a meaningful contribution to the crisis recovery while meeting environmental and social concerns. Our claims have been based on what appears to be a very limited view of "recovery" and indeed "crisis" in terms of how commentators have reported the situation and how economic leaders acted and are acting. It appears as if the wider social crisis is neglected and as such we have sought to redress the balance for Iberian firms by proposing a framework to allow for a more meaningful form of responsible management and to begin to shape an agenda to allow more representative and meaningful measures, monitoring and understanding of the field. It is this agenda that forms our major contribution. However, the heart of our paper has been the concept of mindfulness or as we apply it, mindful leadership. We described a case study where our concept of Mindfulness was implemented in an Iberian multinational organisation. Taking into account the economic and technological importance of this multinational in its sector, and its influential capacity in terms of suppliers and clients, as well as their strong current conviction to implement their next growth strategy through adopting and embedding Responsible Management and Mindful leadership, we think this is a good example of how using mindfulness can help lead other Iberian organisations to champion the recovery from the crisis in the holistic way we have defined. Responsible but also encouraging future business development.

The framework is useful because it can help companies to put the inner potential of organizational members under a shared mindful leadership, to the service of a shared future vision of global performance (not just economic, but also social and environmental) and also break the cycles of sunkcost bias (see Hafenbrack et al 2014 for a discussion of mindfulness as a tool to break sunk cost bias). It is also interesting to remark that this framework is pointing to the deep cause of current socioeconomic crisis, which is a crisis of human values that in business is reflected in unethical behaviours contributing to the breakdown of the basic balances of the socioeconomic and environmental system. We believe that acting in the deep cause level, real solutions to the crisis will be set into action.

While we recognise that our paper has limitations in terms of not having been empirically tested, in parts consolidating the thinking of an emerging field and thus lacking consensus of definition, and overlapping mature with emerging fields in terms of constructs and underpinning, but we believe we make a significant contribution to rethinking the field. In this regard, the limitations offer for opportunities for further research and to extend both context and subject domain. We are heartened by such research opportunities as this paper is in effect the start of a journey not its end. Having developed our framework and identified the core components of it we can now begin to apply and test it in different setting with different stakeholder, across different methodological domains, and with different national cultures (Sims, 2009), shaping future business thinking.

\section{References}

1. Alexander, G.J., \& Buchholz, R.A. (1978). Corporate Social Responsibility and Stock Market Performance. The Academy of Management Journal, 21(3), 479-486.

2. Baron, S.J.F. (2013). Inaction speaks louder than words: The problems of passivity. Business Horizons, 56(3), 301-311.

3. Bartkus, B.R. (2002). Governance and Corporate Philanthropy: Restraining Robin Hood? Business \& Society, 41(3), 319-344.

4. Barthel, P., \& Ivanaj, V. (2007). Is sustainable development in multinational enterprises a marketing issue? Multinational Business Review, 15(1), 67-87.

5. Beams, N. (2013). Global Financial Crisis, tensions at G-20 IMF Meeting: no recovery in sight. Global Research, April 22.

6. Berkovich-Ohana, A., Glicksohn,J., \& Goldstein, A. (2012). Mindfulness-induced changes in gamma band activity - Implications for the default mode network, self-reference and attention. Clinical Neurophysiology, 123(4), 700-710. 
7. Berman, S., Wicks, A., Kotha, S. \& Jones, T. (1999). Does stakeholder orientation matter? The relationship between stakeholder management models and firm financial performance. Academy of Management Journal 42(5) 488-506.

8. Broomhill, R. (2007). Corporate Social Responsibility: Key Issues and Debates. Don Dunstan Foundation for the Dunstan Papers Series No.1.

9. Brown, K. W. \& Ryan, R. M. (2003). The benefits of being present: Mindfulness and its role in psychological well-being. Journal of Personality and Social Psychology, 84, 822-848.

10.Buelens, M., Broeck, V.D. H., Vanderheyden, K., Kreitner, R. \& Kinicki, A. (2006). Organisational Behaviour, 3rd edition, McGraw-Hill Education, Maidenhead.

11.Caldwell, C., Hayes, L.A. \& Long, D.T. (2010). Leadership, Trustworthiness, and Ethical Stewardship. Journal of Business Ethics, 96(4), 497-512.

12.Carroll, A.B. (1999). Corporate Social Responsibility: Evolution of a Definitional Construct. Business Society, $38(3), 268-295$.

13.Carson, J. W.; Carson, K. M; Gil, K. M. \& Baucom, D. H. (2004). Mindfulness-based relationship enhancement. Behavior Therapy, 35(3), 471-494.

14.Carter, C.R. (2008). Purchasing and social responsibility: a replication and extension. Journal of Supply Chain Management, 40(4), 4-16.

15. Chatterji, A. K.; Levine, D. I. \& Toffel M. W. (2009). How well do social ratings actually measure corporate social responsibility? Journal of Economics \& Management Strategy, 18(1), 125-169.

16.Chiesa, A.; Serretti, A. \& Jakobsen,J.A. (2013). Mindfulness: Top-down or bottom-up emotion regulation strategy? Clinical Psychology Review, 33(1), 82-96.

17.Choi, D.Y. \& Gray, E. (2008). Socially responsible entrepreneurs: What do they do to create and build their companies? Business Horizons, 51(4), 341-352.

18.Choi, J. \& Park, B. (2014). Environmentally responsible management of MNE subsidiaries: stakeholder perspective. Multinational Business Review, 22(1), 59-77.

19.Christmann, P. (2004). Multinational companies and the natural environment: determinants of global environmental policy standardization. Academy of Management Journal, 47(5), 747-760.

20.Dashwood, H.S. (2014). Sustainable Development and Industry Self-Regulation: Developments in the Global Mining Sector. Business \& Society, 53(4), 551-582.

21.Dawkins, C. (2002). Corporate welfare, corporate citizenship, and the question of accountability. Business \& Society, 41(3), 269-291.

22.Deen, M. (2013). OECD Forecasts Global Economy to Recover Next Year: Economy. Bloomberg, 29(5).

23.Doh, J.P., Stumpf, S.A. \& Tymon Jr, W.G. (2011). Responsible Leadership Helps Retain Talent in India. Journal of Business Ethics, 98(1), 85-100.

24.Drumwright, M.E. (1994). Socially responsible organizational buying: environmental concern as a noneconomic buying criterion. Journal of Marketing, 58(3), 1-19.

25.Durden, C. (2007). Towards a socially responsible management control system. Accounting, Auditing \& Accountability Journal, 21(5), 671-694.

26.Dyckhoff, H. \& Allen, K. (2001). Measuring ecological efficiency with data envelopment analysis (DEA). European Journal of Operational Research, 132(2), 312-325.

27.Eiadat, Y.; Kelly, A.; Roche, F. \& Eyadat, H. (2008). Green and competitive? An empirical test of the mediating role of environmental innovation strategy. Journal of World Business, 43(2), 131-145.

28.El Dief, M. \& Font, X. (2010). The determinants of hotels' marketing managers' green marketing behaviour. Journal of Sustainable Tourism, 18(2), 157- 174

29.Elkington, J. (1994). Towards the Sustainable Corporation: Win-Win-Win Business Strategies for Sustainable Development. California Management Review, 36(2), 90-100.

30.Epstein-Reeves, J. (2010). Consumers Overwhelmingly Want CSR. Forbes, CSR Blog.

31.Färe, R.; Grosskopf, S., \& Pasurka, C. (2006). Social responsibility: US power plants 1985-1998. Journal of Productivity Analysis, 26(3), 259-267.

32.Fassin, Y. \& Gosselin, D. (2011). The Collapse of a European Bank in the Financial Crisis: An Analysis from Stakeholder and Ethical Perspectives. Journal of Business Ethics, 102(2), 169-191. 
33.Freeman, R.E. \& Auster, E.R. (2011). Values, Authenticity, and Responsible Leadership. Journal of Business Ethics, 98(1), 15-23.

34.Freeman, R.H. (1984). Strategic Management: A Stakeholder Approach, Pitman, Boston, MA.

35.Friedman, A.L. \& Miles, S. (2002). Developing Stakeholder Theory. Journal of Management Studies, 39(1), 1-21.

36.Gardner, W.L.; Cogliser, C.C.; Davis, K.M. \& Dickens, M.P. (2011). Authentic leadership: A review of the literature and research agenda. The Leadership Quarterly, 22(6), 1120-1145.

37.Garland, E.; Gaylord, S. \& Park, J. (2009). The Role of Mindfulness in Positive Reappraisal. EXPLORE: The Journal of Science and Healing, 5(1), 37-44.

38.Gond, J.-P. \& Crane, A. (2009). Corporate social performance disoriented: Saving the lost paradigm? Business \& Society, 49(4), 677-703.

39.Graves, S. \& Waddock, S. (1994). Institutional owners and corporate social performance. Academy of Management Journal, 37(4), 1034-1046.

40.Guay, T.; Doh, J.P. \& Sinclair, G. (2004). Non-Governmental Organizations, Shareholder Activism, and Socially Responsible Investments: Ethical, Strategic, and Governance Implications. Journal of Business Ethics, 52(1), 125139.

41.Gustafson, J. (2006). Corporate Social Responsibility: Are You Giving Back or Just Giving Away? Business: The Ultimate Resource 372, (2nd ed).

42.Habisch, A.; Patelli, L.; Pedrini, M. \& Schwartz, C. (2011). Different talks with different folks: a comparative survey of stakeholder dialog in Germany, Italy, and the U.S. Journal of Business Ethics, 10(3), 381-404.

43.Hafenbrack, A.C; Kinias, Z; \& Barsade, S.G (2014). Debiasing the Mind Through Meditation: Mindfulness and the Sunk-Cost Bias. Psychological Science, 25(2) 369-376.

44.Hansen, E.G. (2009). Responsible Leadership Requires Responsible Leadership Systems: The Case of Merck Ltd., Thailand. SSRN Working Paper Series.

45.Harshman, E.F. \& Harshman, C.L. (1999). Communicating With Employees: Building on an Ethical Foundation. Journal of Business Ethics, 19(1), 3-19.

46.Hart, S. (1995). A Natural-Resource-Based View of the Firm. Academy of Management Review, 20, 986-1014.

47.Henriques, A. (2010). Corporate Impact: Measuring and Managing Your Social Footprint, Earthscan, London.

48.Henriques, I. \& Sadorsky, R.F. (1999). Stakeholders, social responsibility and performance: empirical evidence and theoretical perspectives. Academy of Management Journal, 42(5), 479-487.

49.Hess, M.F. \& Broughton, E. (2014). Fostering an ethical organization from the bottom up and the outside in. Business Horizons, 57(4), 541-549.

50.Hernandez, M. (2008). Promoting Stewardship Behavior in Organizations: A Leadership Model. Journal of Business Ethics, 80(1), 121-128.

51.Hesketh, J. (2006). Educating for responsible management: a South African perspective. Society and Business Review, 1(2), 122-143.

52.Hillman, A.J. (2001). Board Composition and Stakeholder Performance: Do Stakeholder Directors Make a Difference? Business \& Society, 40(3), 295-314.

53.Hollis-Walker,L. \& Colosimo,K. (2011). Mindfulness, self-compassion, and happiness in non-meditators: A theoretical and empirical examination. Personality and Individual Differences, 50(2), 222-227.

54.Hopkins, M. (2009). Strategic CSR and Competitive Advantage, http://mhcinternational.com/articles/strategiccsr-and-competitive-advantage

55.Houdre, H. (2008). Sustainable hospitality: Sustainable development in the hotel industry. Ithaca, NY: Cornell University.

56.Inoune, Y.H. \& Lee, S.K. (2011). Effects of different dimensions of corporate social responsibility on corporate financial performance in tourism-related industries. Tourism Management, 32(4), 790-804.

57.ISO26000 (2010). Social Responsibility http://www.iso.org/iso/home/standards/iso26000.htm.

58.Joyner, B.E. \& Raiborn, C.A. (2005). Management caveats for measuring and assessing public responsibility performance. Business Horizons, 48(6), 525-533.

59.Kabat-Zinn, J. (2003a). Mindfulness-based interventions in context: Past, present, and future. Clinical Psychology: Science and Practice, 10(2), 144-156.

60.Kabat-Zinn, J. (2003b). Mindfulness-based stress reduction (MBSR). Constructivism in the Human Sciences, 8(2), 73-107. 
61.Kempster, S.; Jackson, B. \& Conroy, M. (2011). Leadership as purpose: Exploring the role of purpose in leadership practice. Leadership, 7(3), 317-334.

62.Keng,S. L,; Smoski,M.J. \& Robins, C.J. (2011). Effects of mindfulness on psychological health: A review of empirical studies. Clinical Psychology Review, 31(6), 1041-1056.

63.Kofman, F. \& Senge, P.M. (1993). Communities of commitment: The heart of learning organizations. Organizational Dynamics, 22(2), 5-23.

64.KPMG (2011). KPMG International Survey of Responsibility Reporting, http://www.kpmg.com/PT/pt/IssuesAndInsights/Documents/corporate-responsibility2011.pdf.

65.Kuosmanen, T. \& Kortelainen, M. (2007). Valuing environmental factors in cost-benefit analysis using data envelopment analysis. Ecological Economics, 62, 56-65.

66.Langer, E.J. (1989). Mindfulness. Boston: Addison-Wesley.

67.Loureiro, M.L. \& Lotade,J. (2005). Do fair trade and eco-labels in coffee wake up the consumer conscience? Ecological Economics, 53(1), 129-138.

68.Ludwig, D.S. \& Kabat-Zinn, J. (2008). Mindfulness in medicine. JAMA, 300(11), 1350-1352.

69.Ly,M. \& Spezio, M. L. (2009). The Effect of Meditation on Neural Systems Implicated in Social Judgments. NeuroImage, 47, Supplement 1.

70.Maak, T. \& Pless, N.M. (2006). Responsible Leadership in a Stakeholder Society - A Relational Perspective. Journal of Business Ethics, 66(1), 99-115.

71.Maklan, S. \& Knox, S.D. (2003). CSR at the Crossroads. Edelman, London.

72.Manz, K.P.; Manz, C.C.; Anand, V. \& Joshi, M. (2008). Emerging paradoxes in executive leadership: A theoretical interpretation of the tensions between corruption and virtuous values. The Leadership Quarterly, 19(3), 385-392.

73.Margolis, J. \& Walsh, J. (2003). Misery Loves Company: Rethinking Social Initiatives by Business. Administrative Sciences Quarterly, 48, 268-305.

74.Margolis, J., Elfenbein, H.A , \& Walsh, J. (2007). Does It Pay To Be Good? A Meta-Analysis and Redirection of Research on the Relationship Between Corporate Social and Financial Performance. Presentation at the Academy of Management Meetings, Philadelphia, PA, August.

75.Maturana, H. \& Varela, F. (1987). The tree of knowledge: the biological roots of human understanding.1st edition. Boston: New Science Library.

76.Nijhof, A.; Fisscher, O. \& Looise, J.K. (2000). Coercion, Guidance and Mercifulness: The Different Influences of Ethics Programs on Decision-Making. Journal of Business Ethics, 27(1/2), 33-42.

77.O'Higgins, E. \& Kelleher, B. (2005). Comparative Perspectives on the Ethical Orientations of Human Resources, Marketing and Finance Functional Managers. Journal of Business Ethics, 56(3), 275-288.

78.Pedersen, E.R.G. (2011). All animals are equal, but. . .: management perceptions of stakeholder relationships and societal responsibilities in multinational corporations. Business Ethics: A European Review, 20(2), 177-191.

79.Rana, P.; Platts, J. \& Gregory, M. (2009). Exploration of Corporate Social Responsibility (CSR) in Multinational Companies Within The Food Industry. Queen's Discussion Paper Series on Corporate Responsibility Research, 2.

80.Ravnik-Glavač, M.; Hrašovec,S.; Bon,J.; Dreu,J. \& Glavač,D. (2012). Genome-wide expression changes in a higher state of consciousness. Consciousness and Cognition, 21(3), 1322-1344.

81.Rowley, T. \& Berman, S. (2000). A brand new brand of corporate social performance. Business \& Society, 39(4), 397-418.

82.Russo, M.V. \& Fouts, P.A. (1997). A Resource-Based Perspective on Corporate Environmental Performance and Profitability. Academy of Management Journal, 40(3), 534-559.

83.Salam, M.A. (2009). Corporate Social Responsibility in Purchasing and Supply Chain. Journal of Business Ethics, $85(2), 355-370$

84.Seuring, S.\& Müller. M. (2008). From a literature review to a conceptual framework for sustainable supply chain management. Journal of Cleaner Production, 16(15), 1699-1710.

85.Sheldon, P.J. \& Park, S.Y. (2010). An exploratory study of corporate social responsibility in the U.S. travel industry. Journal of Travel Research, 50(4), 392-407.

86.Sims, R.L. (2009). Collective Versus Individualist National Cultures: Comparing Taiwan and U.S. Employee Attitudes Towards Unethical Business Practices. Business \& Society, 48(1), 39-59. 
87.Sommerville, M. (2013). Nearly half of Britons would buy more from a store that support charity. Retail Gazette, Sept.

88.Spiller, R. (2000). Ethical Business and Investment: A Model for Business and Society. Journal of Business Ethics, 27(1), 149-160.

89.Srivastava, S.K. (2007). Green supply-chain management: A state-of-the-art literature review. International Journal of Management Reviews, 9(1), 53-80.

90.Stanley, S. (2012). Intimate distances: William James' introspection, Buddhist mindfulness, and experiential inquiry. New Ideas in Psychology, 30(2), 201-211.

91.Tams, S. \& Marshall, J. (2011). Responsible careers: Systemic reflexivity in shifting landscapes. Human Relations, 64(1), 109-131.

92.Turban, D. \& Greening, D. (1996). Corporate social performance and organizational attractiveness to prospective employees. Academy of Management Journal, 40(3), 658-672.

93.Ullmann, A. A. (1985), Data in search of a Theory: A critical examination of the relationships among Social Performance, Social Disclosure and Economic Performance of U.S. Firms. The Academy of Management Review, 10(3), 540-557.

94.van Marrewijk, M. (2004). A Value Based Approach to Organization Types: Towards a Coherent Set of Stakeholder-Oriented Management Tools. Journal of Business Ethics, 55(2), 147-158.

95.Visser, W. (2012). The Age Of Responsibility: CSR 2.0 and the New DNA of Business, London: Wiley.

96.Walach, H; Buchheld, N; Buttenmüller, V; Kleinknecht, N \& Schmidt, S (2006). Measuring mindfulness - the Freiburg Mindfulness Inventory. Personality and Individual Differences, 40(8), 1543-1555.

97.WBCSD (2011). World Business Council for Sustainable Development, http://www.wbcsd.org/home.aspx.

98.Weick, K.E. \& Putnam, T. (2006). Organizing for mindfulness: Eastern wisdom and Western knowledge. Journal of Management Inquiry, 15, 275-287.

99.Wilburn, K. \& Wilburn, R. (2014). The double bottom line: Profit and social benefit. Business Horizons, 57(1), 11-20.

100.Williams, G. (2007). Some Determinants of the Socially Responsible Investment Decision: A Cross-Country Study. Journal of Behavioral Finance, 8(1), 43-57.

101.Worden, S. (2003). The Role of Integrity as a Mediator in Strategic Leadership: A Recipe for Reputational Capital. Journal of Business Ethics, 46(1), 31-44. 